\title{
DIURNAL VARIATION IN THE DIURETIC RESPONSE TO INGESTED WATER
}

\author{
By SOLOMON PAPPER ${ }^{1}$ AND JACK D. ROSENBAUM \\ (From the Thorndike Memorial Laboratory, Second and Fourth [Harvard] Medical Services, \\ Boston City Hospital and the Department of Medicine, Harvard Medical School, \\ Boston; and the Medical Service and Research Laboratory, Cushing Veterans \\ Administration Hospital, Framingham, Mass.)
}

(Submitted for publication December 15, 1951 ; accepted February 5, 1952)

In normal individuals the renal excretion of water, sodium, potassium, and uric acid is less at night than during the day. This diurnal variation persists when no food or fluids are taken as well as when identical quantities of food, fluid, and electrolyte are ingested at regular intervals throughout the 24-hour period and is not easily altered by changes in the cycle of sleep and activity (1-12). The nocturnal decrease in excretion of water, sodium, and chloride occurs in spite of recumbent posture, the assumption of which in the daytime tends to augment the urinary output of these substances $(6,10,13-17)$.

The mechanisms involved in the maintenance of the normal diurnal excretory rhythm are obscure. Kleitman suggested decreased nocturnal arterial pressure as a factor (4). Simpson postulated that the low excretion of chloride at night might be related to the acidosis of sleep (18). Stanbury and Thomson noted that the diurnal rhythm appeared to be intimately linked with a simultaneously occurring cycle of acid or alkali excretion (19). Observations in patients with Addison's disease and in individuals receiving cortisone therapy indicate that the adrenal cortical hormones may modify the diurnal excretory rhythm (20-22). Sirota, Baldwin, and Villarreal have demonstrated that the small nocturnal decrease in glomerular filtration rate is of insufficient magnitude to account for nocturnal oliguria, which must therefore depend upon increased tubular reabsorption of water (11).

Blomhert, observing that water loads administered to normal subjects at night evoked a smaller diuresis than did similar loads by day, postulated increased secretion of antidiuretic hormone at

1 United States Public Health Service Postdoctorate Research Fellow in Medicine, Thorndike Memorial Laboratory and Department of Medicine, Harvard Medical School, Boston, Mass. night (23). Under the conditions of his experiments, not only was less water excreted at night, but the rates of sodium and chloride excretion were also much lower than by day. Since it has been shown that the rate of urine flow under conditions of "maximal" water diuresis is related to, and perhaps dependent upon, the concomitant rate of electrolyte excretion (24), it is possible that the diurnal differences in water diuresis noted by Blomhert were secondary to the diurnal rhythm of solute excretion, however the latter may be determined. It seemed important therefore to study water diuresis under conditions such that sodium and chloride excretion were of similar magnitude at night and by day.

\section{EXPERIMENTAL PROCEDURE AND METHODS}

Three young adult male volunteers without evidence of renal or cardiovascular disease served as subjects. The response to administration of a water load was studied four times in each subject: once by day and once at night when a diet poor in sodium was being taken and once again both by day and at night when sodium intake was much larger. Since with a constant intake of sodium at any level, its nocturnal excretion tends to be less than that of the day, an effort was made to achieve excretion rates of comparable magnitude. This was accomplished by carrying out the first study at night, 48 hours after the subject had been taking a diet in which the daily sodium intake was limited to 35 meq., and the second study by day after he had remained on the same diet for an additional 48 hours. The intake of sodium chloride was then increased by giving $40 \mathrm{meq}$. orally as 0.9 per cent saline solution at 6 a.m., noon, 6 p.m. and midnight each day and the studies repeated after several days.

The nocturnal experiments were begun at about midnight without antecedent fluid restriction and were preceded by three to four hours of sleep in Subjects I and II. Subject III remained in bed after 9 p.m. but did not sleep. The daytime experiments were begun between 8 and 9 a.m. after approximately eight hours of sleep followed by a light breakfast at 7 a.m. During each experimental period the subject was awake in a well lighted 
room and remained recumbent throughout except to urinate. The minimum interval between successive studies was 36 hours. At the beginning of each experiment the subject voided, was weighed and then drank $20 \mathrm{ml}$. of tap water per kilogram of body weight within a period of eight to 15 minutes. The resultant water load was maintained for at least two hours after the onset of maximal diuresis by administering sufficient water after each voiding to maintain constant weight throughout the experimental period. Voided urine was collected at intervals of 30 minutes or less after diuresis had begun. Samples of venous blood were taken before water loading and during the period of maximal urine flow.

Sodium and potassium were determined by means of an internal standard flame photometer. Chloride was determined in the urine by the Volhard-Harvey titration (25) and in the serum by the Hald-Patterson technique (26) or the Van Slyke and Hiller modification of the Sendroy procedure (27). The method of Peters (28) was employed for determination of creatinine in urine; for serum the Hare method (29) was utilized.

\section{RESULTS}

The onset of diuresis was delayed at night as contrasted to the day in each of the three subjects, irrespective of salt intake (Table I, Figure 1).

On the second day of the salt-poor regimen, the excretion rates of sodium and chloride at night were slightly higher than those of the daytime stud-

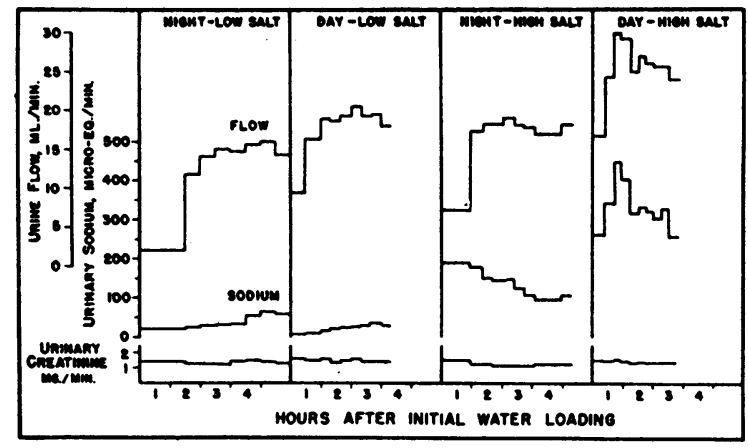

Fig. 1. Rates of Urine Flow, Sodium Excretion, and Creatinine Excretion during Day and Night Water Loads under Conditions of Low Salt and High Salt Diets in SubJect II

ies carried out on the fourth day of salt restriction. Nevertheless the volume of urine excreted during the two-hour period of maximal diuresis at night was slightly less than that excreted during the day. The concentrations of sodium and chloride were necessarily higher in the nocturnal urine.

When the sodium chloride intake was 195 meq. daily, the urine volume, excretion rates of sodium and chloride and urinary concentrations of these ions were all much greater during the day than at night.

TABLE I

Renal excretion of water and electrolytes and serum electrolyte concentrations during constant water load by day and at night

\begin{tabular}{|c|c|c|c|c|c|c|c|c|c|c|c|c|c|c|}
\hline \multirow{3}{*}{$\begin{array}{c}\begin{array}{c}\text { Subject } \\
\text { and diet }\end{array} \\
\text { I } \\
\text { Low salt }\end{array}$} & \multirow{3}{*}{$\begin{array}{c}\text { Time } \\
\begin{array}{c}\text { Night } \\
\text { Day }\end{array}\end{array}$} & \multirow{3}{*}{$\begin{array}{c}\begin{array}{c}\text { Onset of } \\
\text { maximal } \\
\text { diuresis } \\
\text { (minutes } \\
\text { after } \\
\text { loading) }\end{array} \\
\\
65 \\
53\end{array}$} & \multicolumn{7}{|c|}{ Urine* } & \multicolumn{3}{|c|}{ Serumt } & \multicolumn{2}{|c|}{ Creatininet } \\
\hline & & & \multirow{2}{*}{ 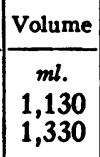 } & \multicolumn{2}{|c|}{ Sodium } & \multicolumn{2}{|c|}{ Potassium } & \multicolumn{2}{|c|}{ Chloride } & \multirow{2}{*}{$\begin{array}{c}\text { Sodium } \\
\text { meq. } / L . \\
137 \\
137\end{array}$} & \multirow{2}{*}{$\begin{array}{c}\text { Potassium } \\
\text { meq./L. } \\
4.3 \\
4.2\end{array}$} & \multirow{2}{*}{$\begin{array}{c}\text { Chloride } \\
\text { meq./L. } \\
103 \\
101\end{array}$} & \multirow{2}{*}{$\begin{array}{l}\mathrm{U} / \mathrm{P} \\
15.5 \\
12.1\end{array}$} & \multirow{2}{*}{$\begin{array}{c}\text { Clearance } \\
\text { ml. } / \min . \\
144 \\
137\end{array}$} \\
\hline & & & & $\begin{array}{r}\text { meq. } \\
6.4 \\
5.2\end{array}$ & \begin{tabular}{|c|} 
meq. $/ L$ \\
5.6 \\
3.9
\end{tabular} & $\begin{array}{r}\text { meq. } \\
9.1 \\
21.3\end{array}$ & $\mid \begin{array}{r}\text { meq. } / L \\
8.0 \\
16.0\end{array}$ & $\begin{array}{r}\text { meq. } \\
8.1 \\
6.5\end{array}$ & \begin{tabular}{|c|} 
meq. $/ L$ \\
7.1 \\
4.8
\end{tabular} & & & & & \\
\hline Low salt & $\begin{array}{c}\text { Night } \\
\text { Day }\end{array}$ & $\begin{array}{r}110 \\
55\end{array}$ & $\begin{array}{l}1,775 \\
2,335\end{array}$ & $\begin{array}{l}4.3 \\
3.1\end{array}$ & $\begin{array}{l}2.4 \\
1.3\end{array}$ & $\begin{array}{r}3.7 \\
15.6\end{array}$ & $\begin{array}{l}2.0 \\
6.7\end{array}$ & $\begin{array}{l}1.0 \\
2.0\end{array}$ & $\begin{array}{l}0.5 \\
0.8\end{array}$ & $\begin{array}{l}140 \\
140\end{array}$ & $\begin{array}{l}4.2 \\
4.2\end{array}$ & $\begin{array}{l}102 \\
103\end{array}$ & $\begin{array}{l}14.5 \\
11.2\end{array}$ & $\begin{array}{l}144 \\
200\end{array}$ \\
\hline $\begin{array}{l}\text { III } \\
\text { Low salt }\end{array}$ & $\begin{array}{c}\text { Night } \\
\text { Day }\end{array}$ & $\begin{array}{r}115 \\
47\end{array}$ & $\begin{array}{l}1,230 \\
1,397\end{array}$ & $\begin{array}{l}5.0 \\
3.3\end{array}$ & $\begin{array}{l}4.0 \\
2.3\end{array}$ & $\begin{array}{r}7.2 \\
10.8\end{array}$ & $\begin{array}{l}5.8 \\
7.7\end{array}$ & $\begin{array}{l}3.1 \\
5.0\end{array}$ & $\begin{array}{l}2.5 \\
3.5\end{array}$ & $\overline{138}$ & $\overline{4.0}$ & $\overline{100}$ & $\overline{13.8}$ & $\overline{143}$ \\
\hline High salt & $\begin{array}{c}\text { Night } \\
\text { Day }\end{array}$ & $\begin{array}{l}76 \\
58\end{array}$ & $\begin{array}{r}885 \\
1,684\end{array}$ & $\begin{array}{r}7.8 \\
28.4\end{array}$ & $\begin{array}{r}8.8 \\
16.8\end{array}$ & $\begin{array}{r}4.2 \\
19.5\end{array}$ & $\begin{array}{r}4.7 \\
11.6\end{array}$ & $\begin{array}{r}7.2 \\
30.5\end{array}$ & $\begin{array}{r}8.1 \\
18.1\end{array}$ & $\begin{array}{l}140 \\
138\end{array}$ & $\begin{array}{l}4.1 \\
4.2\end{array}$ & $\begin{array}{l}111 \\
106\end{array}$ & $\begin{array}{l}20.9 \\
14.7\end{array}$ & $\begin{array}{l}153 \\
181\end{array}$ \\
\hline$\stackrel{\text { II }}{\text { High salt }}$ & $\begin{array}{c}\text { Night } \\
\text { Day }\end{array}$ & $\begin{array}{l}71 \\
37\end{array}$ & $\begin{array}{l}2,175 \\
3,193\end{array}$ & $\begin{array}{l}15.4 \\
41.0\end{array}$ & $\begin{array}{r}7.0 \\
12.9\end{array}$ & $\begin{array}{r}8.2 \\
18.2\end{array}$ & $\begin{array}{l}3.7 \\
5.7\end{array}$ & $\begin{array}{l}12.0 \\
40.9\end{array}$ & $\begin{array}{r}5.5 \\
12.8\end{array}$ & $\begin{array}{l}143 \\
139\end{array}$ & $\begin{array}{l}4.2 \\
4.1\end{array}$ & $\begin{array}{l}105 \\
105\end{array}$ & $\begin{array}{l}8.9 \\
5.5\end{array}$ & $\begin{array}{l}161 \\
162\end{array}$ \\
\hline $\begin{array}{c}\text { III } \\
\text { High salt }\end{array}$ & $\begin{array}{l}\text { Night } \\
\text { Day }\end{array}$ & $\begin{array}{l}85 \\
57\end{array}$ & $\begin{array}{r}888 \\
1,711\end{array}$ & $\begin{array}{r}6.7 \\
15.6\end{array}$ & $\begin{array}{l}7.5 \\
9.1\end{array}$ & $\begin{array}{r}6.6 \\
14.7\end{array}$ & $\begin{array}{l}7.4 \\
8.6\end{array}$ & $\begin{array}{r}6.5 \\
20.0\end{array}$ & $\begin{array}{r}7.3 \\
11.6\end{array}$ & $\begin{array}{l}137 \\
139\end{array}$ & $\begin{array}{l}4.4 \\
4.3\end{array}$ & $\begin{array}{l}104 \\
105\end{array}$ & $\begin{array}{l}16.3 \\
12.9\end{array}$ & $\begin{array}{l}123 \\
160\end{array}$ \\
\hline
\end{tabular}

* Values are for the two-hour period of maximal diuresis.

$\dagger$ Pre-loading values.

$\ddagger 30$ minute collection period during maximal diuresis. 
Although in some instances endogenous creatinine clearances were higher by day and on the higher salt diet, this pattern was inconsistent.

The ratios of the concentrations of creatinine in the urine to those in the plasma $(U / P)$ were consistently higher at night than by day, indicating that a larger fraction of filtered water was reabsorbed by the tubules at night, irrespective of salt intake.

Excretion of potassium was always much greater during the day than at night. In order to determine whether the difference in potassium excretion might explain the nocturnal oliguria, Subject I, while taking the diet poor in sodium, ingested 67 meq. of potassium chloride over a period of one hour and 40 minutes at the height of a nocturnal diuresis. Prior to the administration of potassium chloride, a rate of urine flow of $9.3-9.6 \mathrm{ml} . / \mathrm{min}$. had been achieved (Figure 2). At this time, the rate of potassium excretion was 58-73 microEq./ $\mathrm{min}$. and that of sodium was $40-47 \mathrm{microEq} . / \mathrm{min}$. Following the ingestion of potassium, its excretion reached a height of $301 \mathrm{microEq} . / \mathrm{min}$., associated with an augmentation in the rates of sodium and water excretion to $129 \mathrm{microEq} . / \mathrm{min}$. and $11.0 \mathrm{ml} . / \mathrm{min}$., respectively. During subsequent collection periods, although potassium excretion remained high, the excretion rates of water and sodium declined to below their initial magnitudes. Thus, augmentation of nocturnal water diuresis took place only during the periods when sodium excretion was also greatly increased.

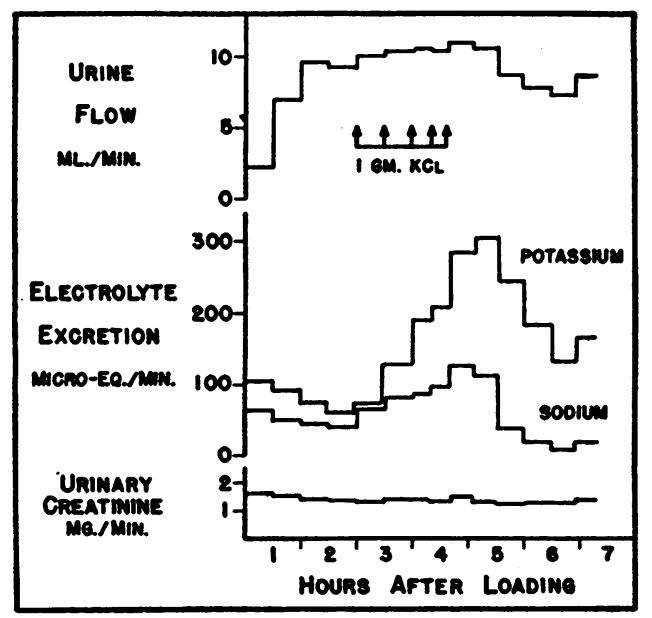

Fig. 2. Nocturnal Potassium Load during "Maximal” Water Diuresis (Subject I)
While the subject was taking the low sodium diet, his maximal potassium excretion during the day was $191 \mathrm{microEq} . / \mathrm{min}$. and was associated with a sodium excretion of $47 \mathrm{microEq} . / \mathrm{min}$. and a urine flow of $11.5 \mathrm{ml} . / \mathrm{min}$. During the night study the rate of urine flow was $8.7 \mathrm{ml} . / \mathrm{min}$. at a time when the potassium excretion was $244 \mathrm{microEq} . / \mathrm{min}$. and the sodium, $36 \mathrm{microEq} . / \mathrm{min}$. Hence, despite a far greater rate of potassium excretion at night in this experiment, the rate of urine flow remained less than by day, except during the period of natriuresis.

While Subject II was on the low salt diet, urea excretion was determined night and day during the period of maximal diuresis. The night and day values were $0.414 \mathrm{mM}$./min. and $0.437 \mathrm{mM}$./min., respectively. Thus, the difference between the night and day response to water loading appears to be unrelated to differences in urea excretion.

\section{DISCUSSION}

Three general mechanisms which might be responsible for the decrease in urine flow which usually occurs at night even when the intake of food, fluid and electrolyte is equally distributed throughout the day and night, require consideration. These are : 1) decreased glomerular filtration rate at night ; 2) decreased sodium excretion and, related to it, decreased urine flow at night; and 3) increased tubular reabsorption of water due to higher levels of activity of antidiuretic hormone $(\mathrm{ADH})$ at night. The available evidence would indicate that the diurnal differences in filtration rate cannot explain the nocturnal suppression of urine flow (11). Our observations that urine flow is less at night in subjects on a salt-poor regimen, under such conditions that nocturnal rates of sodium excretion were slightly higher than those of the day, indicate that the second mechanism cannot under these conditions be responsible. This suggests that increased tubular reabsorption of water alone, presumably as a result of increased $\mathrm{ADH}$ activity at night, might be important. ${ }^{2}$

2 Such increased ADH activity could be due to increased secretion, increased sensitivity of the renal tubules to its action or a decrease in its dissipation. The first hypothesis is the most attractive since under physiologic conditions the rate of $A D H$ secretion is known to vary greatly, whereas the other two phenomena have not been demonstrated. 
Findings consistent with this hypothesis include: 1) higher nocturnal creatinine $U / P$ ratios; 2) higher urinary sodium and chloride concentrations at night; and 3) delay in onset of nocturnal diuresis. Delay in the onset of diuresis after water loading has been shown by Burn and Grewal to be quantitatively related to the size of a dose of exogenous posterior pituitary extract (30).

In the studies conducted while the subjects were taking 195 meq. of sodium daily, far less sodium and chloride were excreted at night than by day, with marked increase in the difference between night and day rates of urine flow. That this difference in flow is related chiefly to salt excretion rather than to increased $\mathrm{ADH}$ activity is suggested by the fact that sodium, chloride and potassium concentrations in the urine were all lower at night. However, the fact that the time interval between water loading and attainment of maximal flow was greater by night than by day in these experiments also indicates that the level of $\mathrm{ADH}$ activity prior to loading was higher at night (30).

The observations described provide no information concerning the basic mechanisms which determine the diurnal rhythm of solute excretion. They do indicate, however, that the diurnal rhythm of water excretion is related both to the excretory rhythm for solute and to diurnal variations in activity of antidiuretic hormone. The former appears to be of greater quantitative significance when salt intake is plentiful. Moreover the relation of the rhythm of water excretion to that of sodium seems clear whereas no association was apparent with the excretion of potassium or urea.

Of interest is the observation that, when the subjects were taking the diet containing 195 meq. of sodium, a sharp increase in sodium excretion took place after the morning water load (Figure 1). This was not observed in the nocturnal experiments. On the contrary, there was a progressive decline in sodium excretion. When the diet was poor in sodium, no such prompt natriuresis occurred either at night or by day. These observations may indicate that under conditions when salt is plentiful, expansion of the volume of body water in the morning is an effective stimulus for significantly increased sodium excretion. It has been demonstrated that the natriuretic response of the kidney to hypotonic expansion of extracellular fluid volume is modified by the posture of the sub- ject (31). It is possible that this response to increased volume is also influenced by the time of day at which the expansion occurs.

\section{CONCLUSIONS}

1. Water loads of $20 \mathrm{ml}$. per kilogram of body weight were instituted and maintained by day and at night in three subjects while they were receiving a diet containing 35 meq. of sodium daily and again when the intake was 195 meq. daily.

2. While the subjects were on the low salt diet during periods in which similar night and day sodium excretion was achieved, definite but slight inhibition of nocturnal water diuresis was demonstrated.

3. When the subjects were on the diet of higher salt content, sodium excretion during the water diuresis was much less at night than during the day. Under these conditions the difference between night and day rates of urine flow was of very large magnitude.

4. It seems probable that the diminished diuretic response to water loading at night is related both to increased nocturnal secretion of antidiuretic hormone and to decreased renal excretion of sodium. The latter appears to be the more important factor when salt intake is liberal.

\section{ACKNOWLEDGMENTS}

The technical assistance of Miss Miriam Halpin, Miss Elsie C. Rossmeisl and Mrs. K. T. Yen is gratefully acknowledged.

The authors wish to express their appreciation to Dr. Maurice B. Strauss for his suggestions and advice in preparing this manuscript.

\section{REFERENCES}

1. Leathes, J. B., On diurnal and nocturnal variations in the excretion of uric acid. J. Physiol., 1906, 35, 125.

2. Cathcart, E. P., Kennaway, E. L., and Leathes, J. B., On the origin of endogenous uric acid. Quart. J. Med., 1907-8, 1, 416.

3. Campbell, J. A., and Webster, T. A., Day and night urine during complete rest, laboratory routine, light muscular work and oxygen administration. Biochem. J., 1921, 15, 660.

4. Kleitman, N., Studies on the physiology of sleep. I. The effects of prolonged sleeplessness on man. Am. J. Physiol., 1923, 66, 67.

5. Simpson, G. E., Diurnal variations in the rate of urine excretion for two hour intervals; some associated factors. J. Biol. Chem., 1924, 59, 107. 
6. Bazett, H. C., Thurlow, S., Crowell, C., and Stewart, W., Studies on the effects of baths on man. II. The diuresis caused by warm baths, together with some observations on urinary tides. Am. J. Physiol., 1924, 70, 430.

7. Manchester, R. C., The diurnal rhythm in water and mineral exchange. J. Clin. Invest., 1933, 12, 995.

8. Jores, A., Physiologie und Pathologie der 24-StundenRhythmik des Menschen. Ergebn. d. inn. Med. u. Kinderh., 1935, 48, 574.

9. Kleitman, N., Biological rhythms and cycles. Physiol. Rev., 1949, 29, 1.

10. Borst, J. G. G., and de Vries, L. A., The three types of "natural" diuresis. Lancet, 1950, 2, 1.

11. Sirota, J. H., Baldwin, D. S., and Villarreal, H., Diurnal variations of renal function in man. J. Clin. Invest., 1950, 29, 187.

12. Mills, J. N., Diurnal rhythm in urine flow. J. Physiol., 1951, 113, 528.

13. White, H. L., Rosen, I. T., Fischer, S. S., and Wood, G. H., The influence of posture on renal activity. Am. J. Physiol., 1926, 78, 185.

14. Ni, T. G., and Rehberg, P. B., On the influence of posture on kidney function. J. Physiol., 1931, 11, 331.

15. Brun, C., Knudsen, E. O. E., and Raaschou, F., Influence of posture on kidney function. I. The fall in the diuresis in the erect posture. Acta med. Scandinav., 1945, 122, 315.

16. Kattus, A. A., Sinclair-Smith, B., Genest, J., and Newman, E. V., The effect of exercise on the renal mechanism of electrolyte excretion in normal subjects. Bull. Johns Hopkins Hosp., 1949, 84, 344.

17. Strauss, M. B., Davis, R. K., Rosenbaum, J. D., and Rossmeisl, E. C., "Water diuresis" produced during recumbency by the intravenous infusion of isotonic saline solution. J. Clin. Invest., 1951, 30, 862.

18. Simpson, G. E., The effect of sleep on urinary chlorides and pH. J. Biol. Chem., 1926, 67, 505.
19. Stanbury, S. W., and Thomson, A. E., Diurnal variations in electrolyte excretion. Clin. Sci., 1951, 10, 267.

20. Levy, M. S., Power, M. H., and Kepler, E. J., The specificity of the "water test" as a diagnostic procedure in Addison's disease. J. Clin. Endocrinol., 1946, 6, 607.

21. Slessor, A., Studies concerning the mechanism of water retention in Addison's disease and in hypopituitarism. J. Clin. Endocrinol., 1951, 11, 700.

22. Rosenbaum, J. D., Ferguson, B. C., Davis, R. K., and Rossmeisl, E. C., The influence of cortisone upon the diurnal rhythm of renal excretory function. J. Clin. Invest., in press.

23. Blomhert, G., Over de Zogenaamde Waterdiurese. Thesis. Amsterdam, 1951.

24. Rosenbaum, J. D., Nelson, W. P., III, and Strauss, M. B., The dependence of water diuresis upon electrolyte excretion. J. Clin. Invest., 1950, 29, 841.

25. Peters, J. P., and Van Slyke, D. D., Quantitative Clinical Chemistry, Vol. II. Methods. Williams \& Wilkins, Baltimore, 1932, pp. 832-835.

26. Peters, J. P., and Van Slyke, D. D., Ibid., pp. 838-839.

27. Van Slyke, D. D., and Hiller, A., Application of Sendroy's iodometric chloride titration to proteincontaining fluids. J. Biol. Chem., 1947, 167, 107.

28. Peters, J. H., The determination of creatinine and creatine in the blood and urine with the photoelectric colorimeter. J. Biol. Chem., 1942, 146, 179.

29. Hare, R. S., Endogenous creatinine in serum and urine. Proc. Soc. Exper. Biol. \& Med., 1950, 74, 148.

30. Burn, G. P., and Grewal, R. S., The antidiuretic response to and excretion of pituitary (posterior lobe) extract in man, with reference to the action of nicotine. Brit. J. Pharmacol., 1951, 6, 471.

31. Strauss, M. B., Davis, R. K., Rosenbaum, J. D., and Rossmeisl, E. C., The production of increased renal sodium excretion by the hypotonic expansion of extracellular fluid volume in recumbent subjects. J. Clin. Invest., 1952, 31, 80. 